\title{
Enhancing Millennial Awareness Towards Marine Litter Through Environmental Education
}

\author{
Ika Kusumawati ${ }^{1, *}$, Mita Setyowati ${ }^{2}$, Agung Dharma Syakti ${ }^{3}$, and Achmad Fahrudin ${ }^{4}$ \\ ${ }^{1}$ Marine Science Department, Teuku Umar University, Meulaboh, West Aceh Regency, Aceh \\ Province, Indonesia \\ ${ }^{2}$ Agrotechnology Department, Teuku Umar University, Meulaboh, West Aceh Regency, Aceh \\ Province, Indonesia \\ ${ }^{3}$ Marine Science and Fishery Faculty, Raja Ali Haji Maritime University, Indonesia \\ ${ }^{4}$ Marine Science and Fishery Faculty, Bogor Agricultural Institute, Bogor, Indonesia
}

\begin{abstract}
One of the influencing factors is the community behavior which reflected public practices in littering. Children are social capital for the community and the essential agents of social change. However, they have issues in recognizing the foundation and the explanation of the environmental problem. The research objectives; to examine millennial perception towards marine litter and the influence of environmental education towards youth perceptions in West Aceh. This study employed a survey approach by distributing questionnaires to 150 respondents from several senior high schools. The data is collected by a questionnaire survey (self-administrative or face-to-face) from January 2019 to June 2019. The researcher distributed questionnaires to students to assess the level of awareness of marine litter. The questionnaire was distributed in two sessions, namely: the first session was before environmental education is given to students; the second session was distributed when students completed environmental education It was found that respondents show low awareness of marine litter according to statistical data but the marine litter short workshop significantly has a positive impact. It concludes that increasing youth awareness through education can be an opening step in combating marine litter to then integrate with approaches to achieve a clean sea.
\end{abstract}

\section{Introduction}

Marine litter is any persistent, manufactured or processed solid material discarded, disposed of or abandoned in the marine and coastal environment [1]. In 1975, the National Academy of Sciences estimated that 14 billion pounds of garbage were being dumped into the ocean every year [2]. It is estimated that a staggering $60-90 \%$ of marine pollution is made up of different types of plastic. The build-up of plastic litter - bottles and cups, plastics found in cigarette filters, straws and other 'macroplastics' (those which are larger than 5mm) - in these urban coastal areas wash out to sea in heavy rain, polluting coastal waters and eventually

\footnotetext{
*Corresponding author: ikakusumawati@utu.ac.id
} 
drifting out to sea [3]. Marine litter is not only an environmental but also health, economic and aesthetic problem [4].

There are many factors that contribute to the accumulation of marine litter, including fishing and shipping activities, tourism and recreational activities, and waste management practices [1]. One of the challenges in reducing marine litter is the difficulty for the consumers to choose products that are environmentally friendly and reusable or recyclable [5].

The community is very influential in the marine litter cycle because it has a role in the shopping cycle and disposal of the remaining products used [6]. For this reason, the action to reduce marine waste through the stages of 5R; Reduce, Reuse, Recycle, Redesign, Recover is very important to be implemented by every stakeholder to protect marine ecosystems from the danger of garbage contamination [4].

However, the low level of public awareness is a constraint in reducing the amount of marine litter. Community behavior in disposing of garbage, especially in developing countries, made Indonesia became the second-highest polluting country after China. Indonesia produced 3.2 million tons of plastic waste in 2010, with around 1.29 million tons of that ending up in the ocean [7]. Therefore, policies in terms of environment and consumers in Europe are very oriented in influencing the habits of consumers. Such a policy is very useful in helping people who care about the dangers of waste to the marine ecosystem and are useful to motivate other people to reduce marine litter [8].

Community behavior in disposing of garbage is strongly influenced by knowledge, attitudes, attention to environmental issues, and motivation to provide solutions [9]. Public perceptions about marine wastes can change if they gain knowledge of related issues and the habit of disposing of garbage can be changed after getting informed about the dangers of marine litter $[9,10]$. For this reason, educational activities that promote the understanding, causes, sources, and impacts of marine waste needed to be applied in tackling the increasing amount of marine litter.

In contrast to the research on the attitudes and behavior of adult environments, there is little literature available on the development of attitudes and behaviors towards the environment. Young people are aware of environmental problems, such as pollution, garbage, and hazardous waste, but they have difficulty understanding the causes and solutions to marine environmental problems [11]. The research objectives were to examine millennial perception towards marine litter and to study the influence of environmental education on youth perceptions in West Aceh City.

\section{Materials and Methods}

\subsection{Respondents and design}

This research was a continuation of previous research titled Community Awareness Analysis of Marine litter in Aceh Province [15]. In the study, many youths and students participated in the conducted survey. The survey involved the participation of 150 students at senior high school from West Aceh District (Fig 1) from age 15 to 18 years old. The quantitative descriptive research design was applied in order to find out how respondents perceive marine waste before and after the educational activities were provided. 


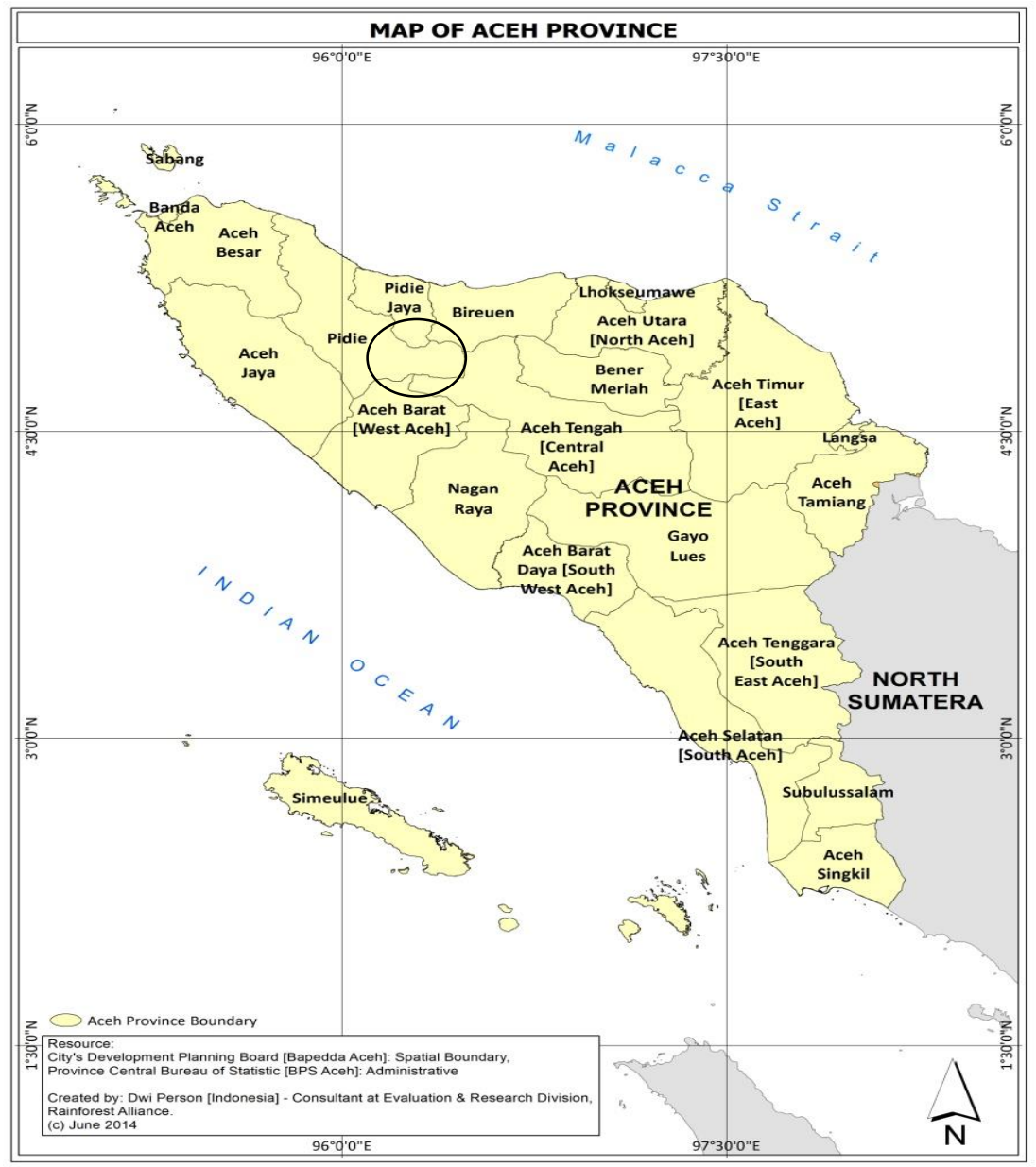

Fig. 1. Map of Aceh, West Aceh Regency with studied areas shaded.

\subsection{Data collection}

The data was collected by questionnaire surveys (self-administrative or face-to-face) from January 2019 to June 2019. The researcher distributed questionnaires to students to assess the level of awareness of marine litter. The questionnaire was distributed in two sessions, namely: the first session was before environmental education is given to students; the second session was distributed when students completed environmental education.

\subsection{Survey of perceptions, attitudes, and behavior}

A short (one-page) survey was developed to assess children's perceptions and behavior regarding marine litter. The categories of questions and certain items in the survey are explained about Problem awareness and concern, Perceived impacts, Perceived causes, and Self-reported litter-reducing behavior. The questionnaire was adapted from a previous study [9]. The questionnaire was confirmed and comprised four parts and 16 questions, including Problem awareness and concern (Do you think litter on the beach and in the sea is a problem?" and "Are you worried about the problems that litter on the beach and in the sea 
might cause?), Perceived impacts (Do you think litter on the beach and in the sea is bad for: (a) Marine wildlife? (b) Tourism? (c) Human health? (d) The fishing industry? and (e) The appearance of the coast?), Perceived causes ("Why is there litter on the beach and in the sea?: (a) Because people drop litter on the beach, (b) Because there are not enough bins, (c) Because businesses (cafes, restaurants, shops) and the fishing industry cause litter at the coast, and (d) Because lots of things we buy have too much packaging that is difficult to recycle), and Self-reported litter-reducing behavior (Have you done the following things in the last week?: (a) Disposed of litter properly? (b) Picked up litter lying around? (c) Recycled? (d) Bought goods with less packaging? and (e) Encouraged family and friends to do any or all of the things above?). Children responded on a four-point scale, not at all, a little bit, quite a bit, and a lot [9].

\section{Results}

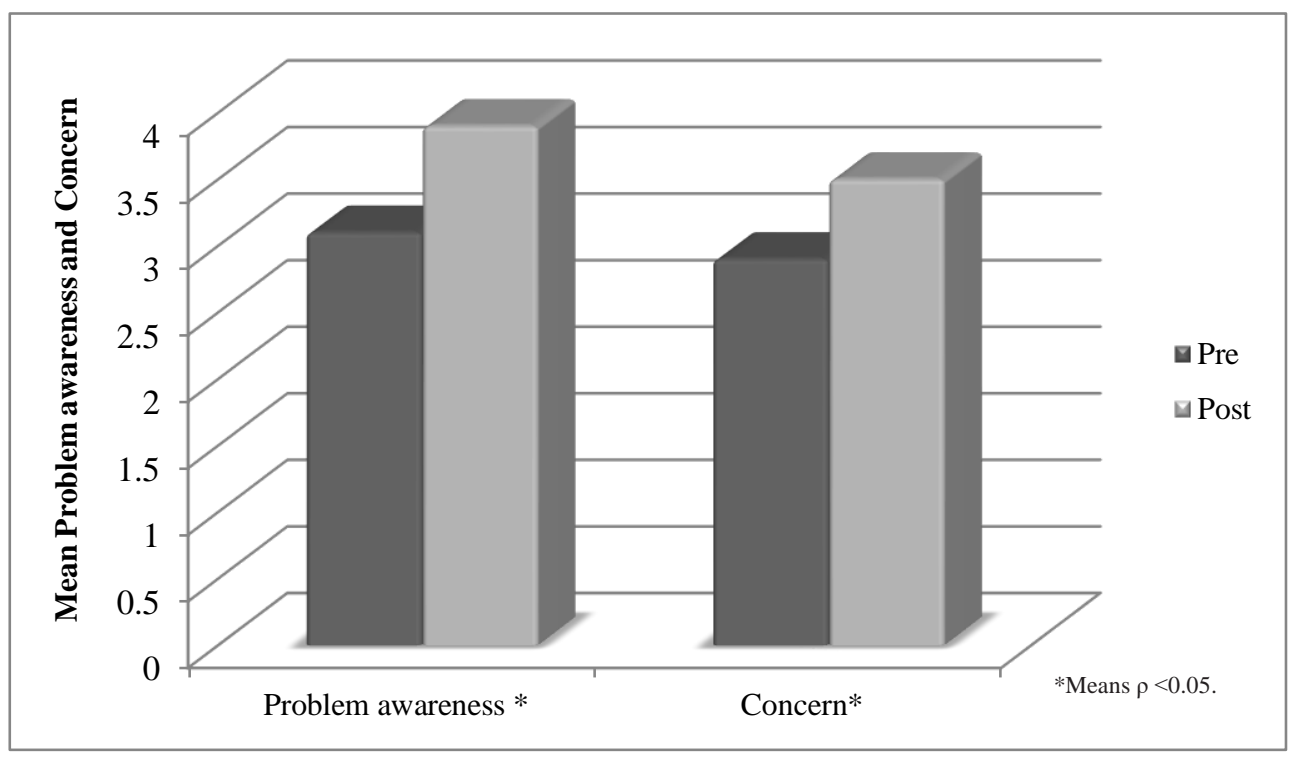

Fig. 2. Problem awareness and concern

The result (Fig.2) shows that there was a significant difference compared between preintervention and post-intervention $(\rho<0.05)$. The children recognized that marine litter is an important problem that harms the environment, the coastal industry, and human health. Children in the current study perceived that marine litter posed the greatest threat to marine wildlife and viewed the threat to human health as one of the lowest impacts (figure 3). Children's perceptions about all impacts of marine litter significantly increased after taking part in the intervention. 


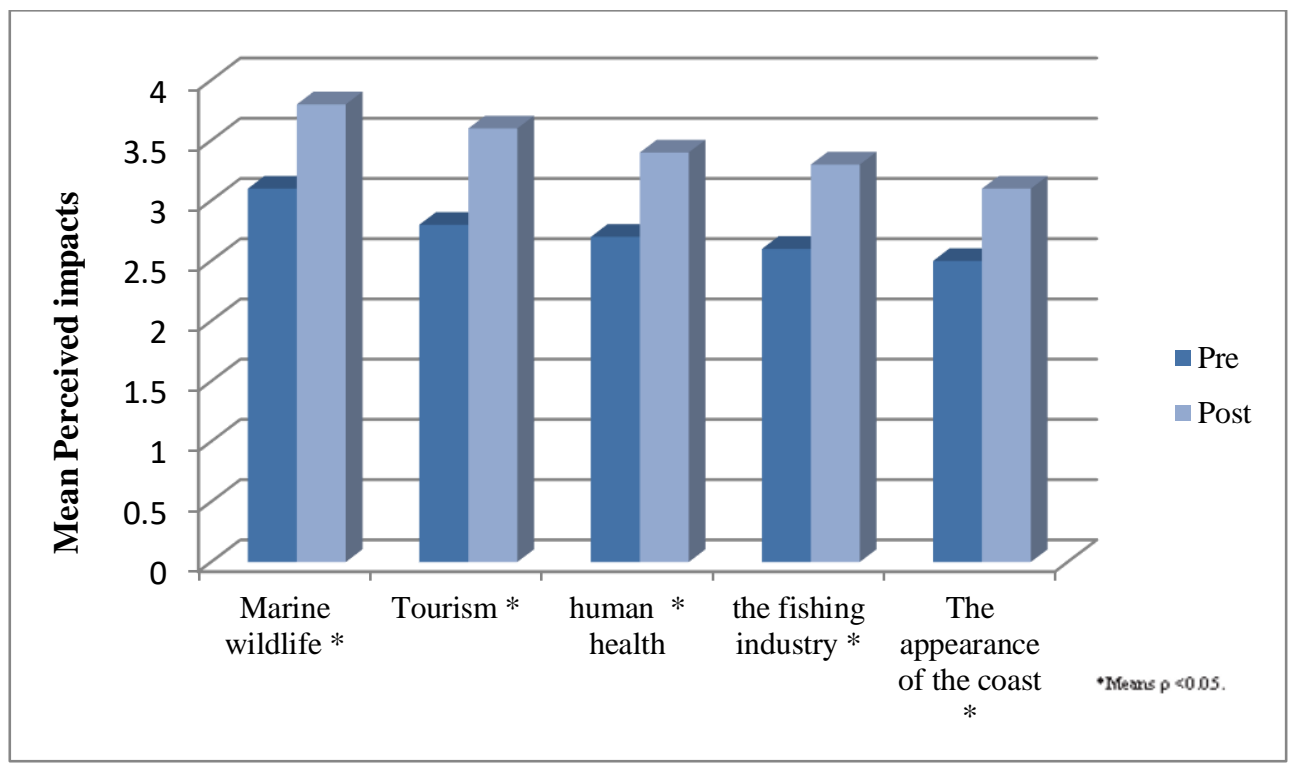

Fig. 3. Perceived impacts

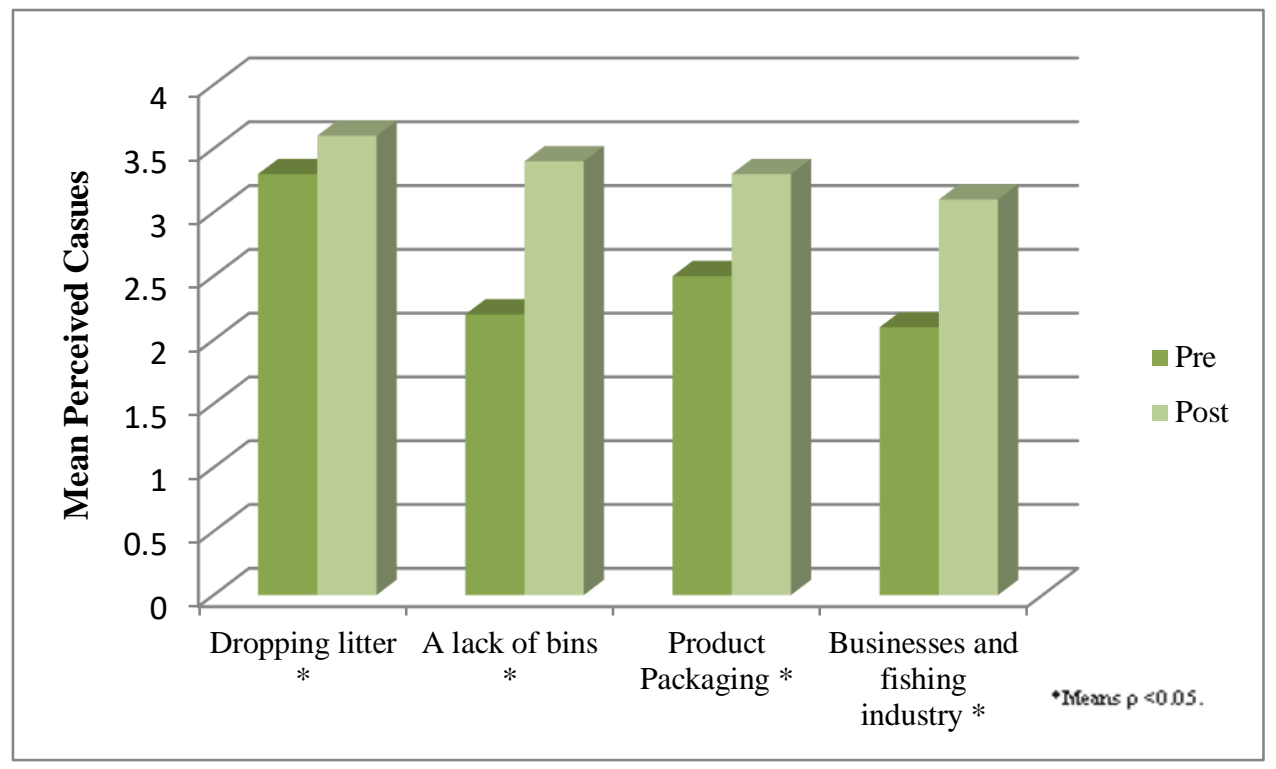

Fig. 4. Perceived causes

Children's perceptions about the extent that dropping litter and a lack of bins contribute to marine litter (figure 4). Respondent reported encouraging family and friends to perform more litter-reducing behaviors (figure 5). children's perceptions about Self-reported litterreducing behavior (except Recycled and Less Packaging) significantly increased after taking part in the intervention. 


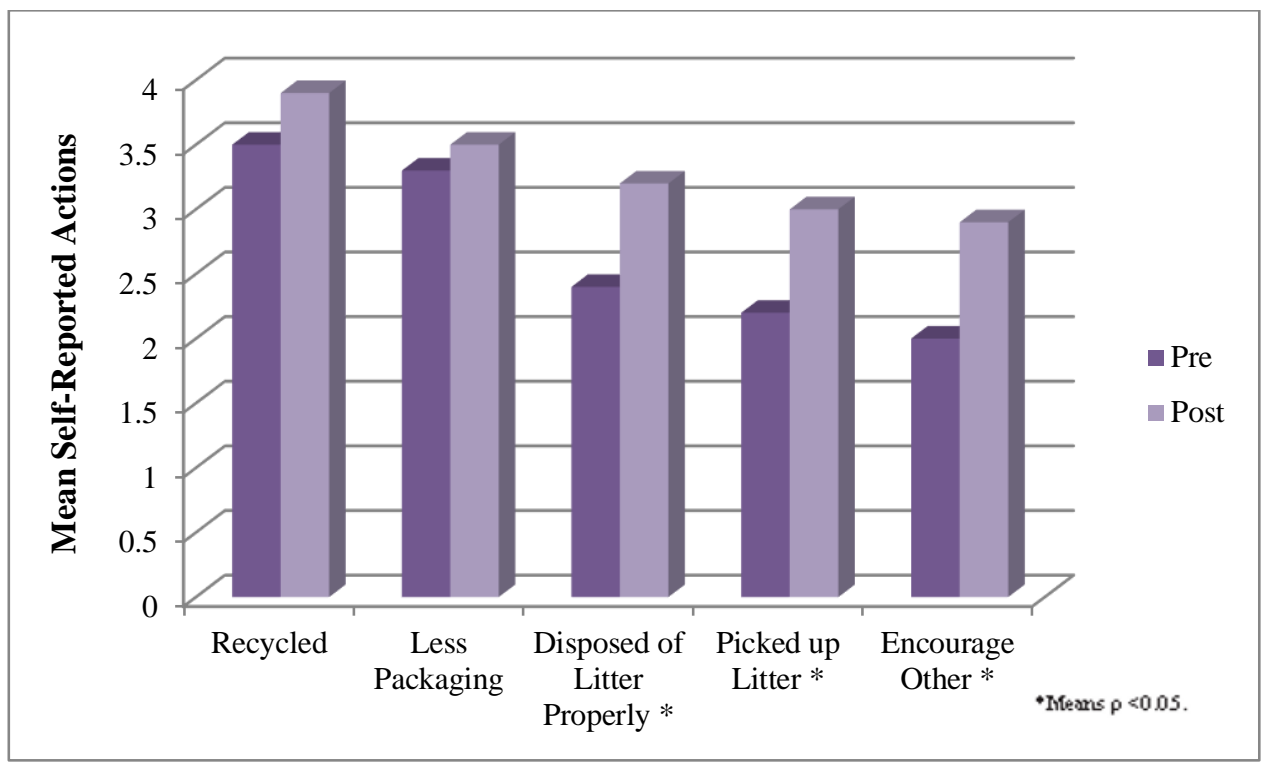

Fig.5. Self-reported litter-reducing behavior

\section{Discussions}

The most visible and disturbing impacts of marine plastics are the ingestion, suffocation, and entanglement of hundreds of marine species. Marine wildlife such as seabirds, whales, fishes, and turtles, mistake plastic waste for prey, and most die of starvation as their stomachs are filled with plastic debris. Floating plastics also contribute to the spread of invasive marine organisms and bacteria, which disrupt ecosystems. Invisible plastic has been identified in tap water, salt and is present in all samples collected in the world's oceans, including the Arctic. Several chemicals used in the production of plastic materials are known to be carcinogenic and to interfere with the body's endocrine system, causing developmental, reproductive, neurological, and immune disorders in both humans and wildlife [17]. The study conducted by [18] mentioned that the impacts of plastics are related to their excessive abundance in allnatural environments, their high persistence (because complete mineralization takes place after hundreds or perhaps thousands of years), the formation of toxic substances, and their ability to act as a vector for contaminants, including persistent organic pollutants (POPs) and heavy metals. Similar findings were reported by [19] that marine litter deteriorates into tiny fragments known as microplastics with other elements and added sun exposure causing problems as they enter the food chain, posing threats to marine life, coral reefs, coastal ecosystems, and human health. It is one of the most widespread and pervasive pollution problems affecting the world's valuable natural resources: our oceans, coral reefs, fisheries, and marine wildlife.

The children were somewhat aware of the composition and hazards of marine litter and reportedly involved in several behaviors that can reduce marine waste. It is interesting to note that the children showed a certain level of awareness of the problem and already had a positive ongoing behavior before participating in the educational activities. Environmental education encourages young people to become concerned and aware of the marine litter problem. Some children's responses appear to be consistent with the responses given by adults in previous studies when observing beach users or people who were littering at the beach as the main source of beach litter [13]. Whereas [12] found that adults perceived the 
threat to human health and safety as the main problem caused by marine litter. The problem of marine litter is inseparable from the lack of community role in maintaining hygiene, especially due to the current culture of the local people who have not been aware of not littering, and also exacerbated with minimal communication effort between stakeholders to manage waste [16]. The result of self-reported litter-reducing behavior (except Recycled and Less Packaging) significantly increased after taking part in the intervention. This is consistent with previous research on environmental education learning which has shown that children can influence the environmental knowledge, attitudes, and behaviors of adults in various domains [14].

This research raised awareness, altered perceptions and improved behavior for reducing self-reported waste. Environmental education should encourage young people to become agents of change that are more caring, informed and competent. Through education, hopefully, they can influence family members, peers, and the wider community. Raising youth awareness through education can be the first step in combating marine litter and then integrating it with other approaches in order to clean the ocean.

We would like to thank the Directorate of Research and Community Service (Direktorat Riset dan Pengabdian Masyarakat/DRPM) of The Ministry of Research and Higher Education (Kementerian Ristek Dikti) of Indonesia for funding this research through the "skema hibah Penelitian Kerjasama antar Perguruan Tinggi”.

\section{References}

1. F. Galgani, D. Fleet, J.V. Franeker, S. Katsanevakis, T. Maes, J. Mouat, L. Oosterbaan, I. Poitou, G. Hanke, R. Thompson, E. Amato, A. Birkun, dan C. Janssen. Marine Strategy Framework Directive-Task Group 10 Report Marine Litter. Scientific and Technical Reports (ed. $N$ Zampoukas). European Commission Joint. Research Centre. Ispra. (2010)

2. J. Hetherington, J. Leous, J. Anziano, D. Brockett, A. Cherson, E. Dean, J. Dillon,

T. Johnson, M. Littman, N. Lukehart J. Ombac, K. Reilly, The Marine Litter Research, Prevention and Reduction Act: A Policy Analysis. Columbia University New York, New York. (2005)

3. D.K. Barnes, F. Galgani, R.C. Thompson, M. Barlaz, Accumulation and

fragmentation of plastic litter in global environments. Philos. Trans. Roy. Soc. B: Biol. Sci. 364, 1985-1998. (2009)

4. STAP. Marine litter is a global environmental problem: introducing a solutions-based framework focused on plastic. In: A STAP Information Document. Global Environment Facility, Washington, DC. (2011)

5. E. Röös, H. Tjärnemo, Challenges of carbon labeling of food products: a consumer research perspective. British Food Journal, Vol. 113 Issue: 8, pp.982-996, https://doi.org/10.1108/00070701111153742 (2011)

6. European Commission: DG XI, 1998. Integrated product policy. A study analyzing national and international developments concerning integrated product policy in the environment field and providing elements for an EC policy in this area. An executive summary from the final report. <http://ec.europa.eu/environment/ipp/pdf/ippsum.pdf>. (1998).

7. J. R. Jambeck, G. Roland, W. Chris, S.R. Theodore, P. Miriam, A. Anthony, N. Ramani, and L. Kara, Plastic Waste Inputs From Land Into The Ocean. Journal. Science Vol. 347, Issue 6223, pp. 768-771. (2015) 
8. C. Leire, A. Thidell. Product-related environmental information to guide consumer purchases-a review and analysis of research on perceptions, understanding, and use among Nordic consumers. J. Cleaner Prod. 13, 1061-1070. http://dx.doi.org/10.1016/j.jclepro.2004.12.004 (2005)

9. B.L. Hartley, R.C. Thompson, and S. Pahl, Marine Litter Education Boosts Children Understanding and Self-Reported Actions. Marine Pollution Bulletin 90: 209-217. (2015)

10. K. Wyles, S. Pahl, M. White, S. Morris, D. Snelling, R.C. Thompson, Towards a marine mindset: visiting an aquarium can improve attitudes and intentions regarding marine sustainability. Visitor Stud. 16, 95-110. (2013)

11. P.H. Kahn Jr., O. Lourenco, Water, air, fire, and earth: a developmental study in Portugal of environmental moral reasoning. Environ. Behav. 34, 405-430. http://dx.doi.org/10.1177/00116502034004001 (2002)

12. I.R. Santos, A.C. Friedrich, M. Wallner-Kersanach, G. Fillmann, Influence of socioeconomic characteristics of beach users on litter generation. Ocean Coast. Manage. 48, 742-752. http://dx.doi.org/10.1016/j.ocecoaman.2005.08.006. (2005)

13. M.L. Campbell, C. Paterson de Heer, A. Kinslow, Littering dynamics in a coastal industrial setting: the influence of non-resident populations. Mar. Pollut. Bull. 80, 179185. http://dx.doi.org/10.1016/j.marpolbul.2014.01.015. (2014)

14. P. Damerell, C. Howe, E.J. Milner-Gulland, Child-orientated environmental education influences adult knowledge and household behavior. Environ. Res. Lett. 8, 1501615022. http://dx.doi.org/10.1088/1748-9326/8/1/015016. (2013)

15. I. Kusumawati et al IOP Conf. Ser.: Earth Environ. Sci. 139012031 (2018)

16. J. M. Veiga, T. Vlachogianni, S. Pahl, R. C. Thompson, K. Kopke, T. K. Doyle, B. L. Hartley, T. Maes, D. L. Orthodoxou, X. I. Loizidou, and I. Alampei. Marine Pollution Bulletin 102 (2) 309-315 (2016)

17. https://www.iucn.org/resources/issues-briefs/marine-plastics 27 October 2019

18. A. T. Williams, and N. Rangel-Buitrago. Marine litter: Solutions for a major environmental problem. Journal of Coastal Research, 35(3), 648-663. Coconut Creek (Florida), ISSN 0749-0208. (2019)

19. http://cep.unep.org/unep2019s-caribbean-environment-programme-reminds-of-thedeadly-impact-of-marine-litter-on-the-ocean 28 october 2019 